\title{
Pemahaman Konsep Tata Nama Senyawa Biner Dan Poliatomik Pasca Pembelajaran Menggunakan LKS-Deduktif Dan LKS- Induktif Pada Siswa Kelas X SMA Negeri 2 Palangka Raya Tahun Ajaran 2018/2019
}

\author{
Olvi Wulan Nari $^{1 *}$, Abudarin $^{1}$, Karelius ${ }^{2}$ \\ ${ }^{1}$ Program Studi Pendidikan Kimia, Universitas Palangka Raya, Indonesia \\ ${ }^{2}$ Program Studi Kimia, Universitas Palangka Raya, Indonesia \\ *Email: olviwulannari@gmail.com
}

\begin{abstract}
Abstrak
Ada dua strategi belajar yang dapat digunakan siswa dalam mempelajari pengetahuan yaitu menggunakan strategi berpikir deduktif maupun induktif. Tujuan penelitian ini untuk mendeskripsikan pemahaman konsep tata nama senyawa biner dan poliatomik pasca pembelajaran menggunakan LKS-deduktif dan LKS-induktif pada siswa kelas X SMA Negeri 2 Palangka Raya tahun ajaran 2018/2019.

Penelitian ini merupakan penelitian deskriptif dan melibatkan 78 siswa dari dua kelas X SMA Negeri 2 Palangka Raya, yaitu siswa kelas X IPA 3 (kelas deduktif) sebanyak 40 orang siswa dan siswa kelas X IPA 7 (kelas induktif) sebanyak 38 orang siswa. Instrumen yang digunakan berupa LKS-deduktif, LKSinduktif dan soal tes pemahaman konsep. Data tes diperoleh setelah melakukan pembelajaran menggunakan LKS-deduktif dan LKS-induktif.

Hasil penelitian menunjukkan bahwa "pemahaman konsep tata nama senyawa biner dan poliatomik pasca pembelajaran menggunakan LKS-deduktif dan LKS-induktif pada siswa kelas X SMA Negeri 2 Palangka Raya tahun ajaran 2018/2019 tergolong baik. Rata-rata pemahaman konsep siswa yang menggunakan LKS-deduktif sedikit lebih tinggi dibandingkan siswa yang menggunakan LKS-induktif. Hasil tersebut disebabkan karena siswa terbiasa menggunakan strategi belajar deduktif."
\end{abstract}

Kata kunci: Tata nama senyawa, anorganik, LKS, deduktif, induktif. 


\section{Pendahuluan}

Ilmu kimia merupakan konsep-konsep yang berjenjang, oleh karenanya siswa perlu memahami konsep dasar dengan benar. Gejala yang banyak ditemukan di sekolah adalah kesulitan siswa dalam memahami konsep dasar kimia secara terstruktur dan berkesinambungan. Kesulitan ini akan mengakibatkan masalah yang lebih luas terutama dalam memahami tingkat penguasaan konsep kimia yang lebih tinggi. Salah satu kesulitan yang dialami siswa saat belajar kimia yaitu tidak memahami konsep pada materi penamaan senyawa anorganik. Penelitian oleh Hengki (2015) tentang pemahaman konsep tata nama senyawa biner dan poliatomik dalam pembelajaran menggunakan metode diskusi dengan berbantuan LKS-deduktif pada siswa kelas X SMK Negeri 1 Palangka Raya tahun ajaran 2014/2015 mengalami peningkatan pemahaman konsep. Peningkatan pemahaman konsep tata nama senyawa biner dan poliatomik pada penelitian Hengki pasca pembelajaran (tes akhir) sebesar 74,12\%.

Tujuan dari penamaan senyawa ialah untuk memudahkan dalam membedakan senyawa dengan sifat fisis yang sama. Tata nama senyawa merupakan serangkaian aturan dalam persenyawaan-persenyawaan kimia yang disusun secara sistematis. Hasil penelitian ini memperkaya kajian tentang pembelajaran kimia, khususnya pada materi tata nama senyawa biner dan poliatomik menggunakan LKS-deduktif dan LKS-induktif.

Ada dua alur berpikir yang dapat digunakan dalam mempelajari tata nama senyawa, yaitu alur berpikir deduktif dan induktif. Lembar kerja dengan alur penalaran deduktif merupakan salah satu bahan ajar berupa lembaran kerja yang dirancang menggunakan alur berpikir deduktif. Lembar kerja dengan alur 
penalaran induktif merupakan salah satu bahan ajar berupa lembaran kerja yang dirancang menggunakan alur berpikir induktif. Berdasarkan paparan di atas, maka perlu diteliti bagaimana pemahaman konsep tata nama senyawa biner dan poliatomik pasca pembelajaran menggunakan LKS dengan strategi belajar deduktif (LKS-deduktif) dan LKS dengan strategi belajar induktif (LKS-induktif) pada siswa kelas X SMA Negeri 2 Palangka Raya tahun ajaran 2018/2019.

Tujuan dari penelitian ini adalah mendeskripsikan pemahaman konsep tata nama senyawa biner dan poliatomik pasca pembelajaran menggunakan LKSdeduktif dan LKS-induktif pada siswa kelas X SMA Negeri 2 Palangka Raya tahun ajaran 2018/2019. Instrumen yang digunakan berupa LKS-deduktif, LKSinduktif dan soal tes pemahaman konsep. Data tes diperoleh setelah melakukan pembelajaran menggunakan LKS-deduktif dan LKS-induktif.

Konsep merupakan simbol berpikir. Hal ini diperoleh dari hasil memuat tafsiran terhadap fakta atau realita, dan hubungan antara berbagai fakta. Suatu konsep dapat diklasifikasi berdasarkan ciri tertentu, misalnya konsep tentang manusia, konsep burung, konsep ikan, dan lain-lain. Kemampuan seseorang dapat membentuk konsep apabila orang tersebut dapat melakukan diskriminasi (Uno, 2006). Pemahaman konsep adalah cara memahami sesuatu yang sudah terpola dalam pikirannya yang diakses oleh simbol verbal atau tertulis. Seorang siswa apabila dirinya sudah memahami konsep, artinya konsep tersebut sudah tersimpan dalam pikirannya berdasarkan pola-pola tertentu yang dibutuhkan oleh siswa untuk ditetapkan dalam pikiran mereka sendiri sebagai ciri dari non contoh (Costa, 1988). 
Lembar kerja siswa (student work sheet) adalah lembaran-lembaran berisi tugas yang harus dikerjakan oleh peserta didik. Lembar kegiatan biasanya berupa petunjuk, langkah-langkah untuk menyelesaikan suatu tugas. Lembar kegiatan dapat digunakan untuk mata pelajaran apa saja. Tugas-tugas sebuah lembar kegiatan tidak dapat dikerjakan oleh peserta didik secara baik apabila tidak dilengkapi dengan buku lain atau referensi lain yang terkait dengan materi tugasnya. Tugas-tugas yang diberikan kepada peserta didik dapat berupa teoritis dan atau tugas-tugas praktis (Majid, 2005).

Pendekatan deduktif merupakan pemberian tentang prinsip-prinsip isi pelajaran, kemudian dijelaskan dalam bentuk penerapannya atau contohcontohnya dalam situasi tertentu. Pendekatan ini menjelaskan teoritis ke bentuk realitas atau menjelaskan hal-hal yang bersifat umum ke hal-hal yang bersifat khusus (Yamin, 2013). Pendekatan pembelajaran induktif merupakan pendekatan yang dimulai dengan pemberian fakta, kasus, contoh, atau sebab yang mencerminkan suatu konsep atau prinsip. Peserta didik kemudian dibimbing untuk berusaha keras mensintesiskan, menemukan, dan menyimpulkan prinsip dasar dari pendekataan tersebut (Yamin, 2013). Menurut Arikunto (2010), penelitian deskriptif yaitu penelitian yang dimaksudkan untuk mengumpulkan informasi mengenai status suatu gejala yang ada, yakni keadaan, gejala yang menurut apa adanya pada saat penelitian dilakukan.

\section{Metodologi Penelitian}

Jenis penelitian yang digunakan dalam penelitian ini adalah penelitian deskriptif. Penelitian ini terbagi dalam dua kelas, yaitu kelas deduktif dan kelas 
induktif. Kelas deduktif adalah kelas yang diberikan perlakuan dengan pembelajaran menggunakan LKS-deduktif sedangkan kelas induktif adalah kelas yang diberikan perlakuan dengan pembelajaran menggunakan LKS-induktif. Instrumen yang digunakan untuk mengumpulkan data pemahaman konsep dalam penelitian ini berupa soal essay berjumlah empat soal. Soal nomor 1 terdiri dari tiga butir soal, soal nomor 2 terdiri dari dua butir soal, nomor 3 terdiri dari tiga butir soal, dan soal nomor 4 terdiri dari dua butir soal. Tes diberikan untuk mengetahui pemahaman siswa terhadap tata nama senyawa biner dan poliatomik setelah pemberian LKS. Instrumen yang digunakan sesuai dengan indikator dan mengacu pada kurikulum 2013. LKS-deduktif adalah LKS yang dirancang untuk menuntun siswa berpikir deduktif yang mempelajari sesuatu yang bersifat umum terlebih dahulu kemudian menarik kesimpulan yang bersifat khusus. LKS-induktif adalah LKS yang dirancang untuk menuntun siswa berpikir induktif yang mempelajari sesuatu yang bersifat khusus untuk menentukan kesimpulan yang bersifat umum. Analisis data pemahaman konsep dilakukan dengan beberapa langkah sebagai berikut:

1. Pemeriksaan hasil tes siswa dilakukan dengan memberi skor pada lembar jawaban. Jika jawaban benar diberi skor "1" dan jika jawaban salah diberi skor “0”. Langkah selanjutnya yaitu menjumlahkan skor yang diperoleh masing-masing siswa dan mengkonversikan dalam bentuk nilai dengan rumus sebagai berikut:

$$
\text { Nilai }=\frac{\text { jumlah skor yang diperoleh siswa }}{\text { jumlah skor total }} \times 100
$$

2. Mentabulasi hasil tes siswa yang sudah dalam bentuk persentase pemahaman dan memberikan kode pada setiap siswa. 
3. Menentukan kriteria tingkat pemahaman siswa berdasarkan pedoman yang digunakan.

Tabel 5. Klasifikasi Tingkat Pemahaman

\begin{tabular}{ccc}
\hline Tingkat Pemahaman & Persentase Pemahaman (\%) & Kriteria \\
\hline I & $30-39$ & Kurang sekali \\
II & $40-45$ & Kurang \\
III & $56-65$ & Cukup \\
IV & $66-79$ & Baik \\
V & $80-100$ & Baik sekali \\
\hline
\end{tabular}

(Arikunto, 2013)

\section{Hasil Penelitian Dan Pembahasan}

Proses pembelajaran untuk mengumpulkan data kelas deduktif dilakukan pada hari Selasa, 26 Maret 2019 yang melibatkan 40 siswa kelas X IPA 3 SMA Negeri 2 Palangka Raya tahun ajaran 2018/2019 sebagai kelas deduktif dengan alokasi waktu 3x45 menit (3 jam pelajaran). Deskripsi data hasil penelitian kelas deduktif terdiri dari data nilai LKS dan data tes akhir. Proses pembelajaran untuk pengumpulan data kelas induktif dilakukan pada hari Senin, 25 Maret 2019 yang melibatkan 38 orang siswa kelas X IPA 7 SMA Negeri 2 Palangka Raya tahun ajaran 2018/2019 sebagai kelas induktif dengan alokasi waktu 3x45 menit (3 jam pelajaran). Deskripsi data hasil penelitian kelas deduktif terdiri dari data nilai LKS dan data tes akhir.

Data yang dikumpulkan pada penelitian ini berupa jawaban tes yang mencakup pencapaian 10 indikator. Indikator 1 menuliskan nama senyawa biner antar dua unsur nonlogam tanpa indeks; indikator 2 menuliskan nama senyawa antar dua unsur nonlogam jika salah satu unsurnya memiliki indeks; indikator 3 menuliskan nama senyawa antar dua unsur nonlogam jika kedua unsur memiliki indeks; indikator 4 menuliskan nama senyawa antar unsur logam dan nonlogam jika unsur logam memiliki satu bilangan oksidasi; indikator 5 menuliskan nama 
senyawa antar unsur logam dan nonlogam jika unsur logam memiliki bilangan oksidasi lebih dari satu; indikator 6 menuliskan nama senyawa poliatomik jika kation memiliki satu bilangan oksidasi; indikator 7 menuliskan nama senyawa basa; indikator 8 menuliskan nama senyawa poliatomik jika kation memiliki bilangan oksidasi lebih dari satu; indikator 9 menuliskan nama senyawa asam jika unsur hidrogen tidak memiliki indeks; dan indikator 10 menuliskan nama senyawa asam jika unsur hidrogen memiliki indeks.

Penelitian ini dilaksanakan pada dua kelas yaitu kelas deduktif dan kelas induktif, di mana kelas deduktif diberikan perlakuan berupa pembelajaran menggunakan LKS-deduktif sedangkan kelas induktif diberikan perlakuan berupa pembelajaran menggunaan LKS-induktif. Penelitian ini bertujuan untuk mendeskripsikan pemahaman konsep tata nama senyawa biner dan poliatomik dengan menggunakan LKS-deduktif dan LKS-induktif pada siswa kelas X SMA Negeri 2 Palangka Raya tahun ajaran 2018/2019.

Penelitian ini dilaksanakan melalui dua tahap yaitu pembelajaran menggunakan LKS-deduktif untuk kelas deduktif, pembelajaran menggunakan LKS-induktif untuk kelas induktif, dan tes. Pemberian LKS berlangsung selama \pm 90 menit dengan tujuan mengumpulkan data pemahaman konsep siswa dalam tata nama senyawa biner dan poliatomik. Tes berlangsung selama \pm 20 menit dengan tujuan mengumpulkan data pemahaman konsep siswa dalam tata nama senyawa biner dan poliatomik setelah pemberian LKS. Tabel 10 menunjukkan deskripsi hasil pemahaman konsep siswa tes untuk kelas deduktif dan kelas induktif pada materi tata nama senyawa. 
Tabel 10. Data Pemahaman Siswa pada Tes untuk Kelas Deduktif dan Kelas Induktif

\begin{tabular}{|c|c|c|c|c|c|}
\hline \multirow{2}{*}{$\begin{array}{l}\text { Kode } \\
\text { Siswa }\end{array}$} & \multicolumn{2}{|c|}{ Kelas Dedultif } & \multirow{2}{*}{$\begin{array}{l}\text { Kode } \\
\text { Siswa }\end{array}$} & \multicolumn{2}{|c|}{ Kelas Indulatif } \\
\hline & $\begin{array}{c}\text { Kemampunn } \\
\text { Belajar }\end{array}$ & $\begin{array}{c}\text { Pemabaman } \\
\text { Konsep }\end{array}$ & & $\begin{array}{c}\text { Kemampunn } \\
\text { Belajar }\end{array}$ & $\begin{array}{c}\text { Pemahaman } \\
\text { Konsep }\end{array}$ \\
\hline $\mathrm{D}-01$ & 100 & 100 & $\mathrm{I}-01$ & 100 & 100 \\
\hline $\mathrm{D}-02$ & 100 & 100 & $\mathrm{I}-02$ & 95,35 & 90 \\
\hline $\mathrm{D}-03$ & 90,79 & 90 & $\mathrm{I}-03$ & 79,07 & 70 \\
\hline$D-04$ & 93,42 & 90 & $\mathrm{I}-04$ & 94,18 & 90 \\
\hline $\mathrm{D}-05$ & 88,16 & 80 & $\mathrm{I}-05$ & 95,35 & 90 \\
\hline $\mathrm{D}-06$ & 97,37 & 80 & $\mathrm{I}-06$ & 83,72 & 70 \\
\hline $\mathrm{D}-07$ & 78,95 & 80 & $\mathrm{I}-07$ & 93,02 & 90 \\
\hline $\mathrm{D}-08$ & 92,11 & 80 & $\mathrm{I}-08$ & 76,74 & 90 \\
\hline $\mathrm{D}-09$ & 92,11 & 70 & $\mathrm{I}-09$ & 89,39 & 90 \\
\hline$D-10$ & 75,00 & 50 & $\mathrm{I}-10$ & 100 & 100 \\
\hline D-11 & 86,84 & 80 & I-11 & 86,05 & 90 \\
\hline $\mathrm{D}-12$ & 100 & 100 & $\mathrm{I}-12$ & 100 & 100 \\
\hline $\mathrm{D}-13$ & 94,74 & 60 & I-13 & 77,91 & 70 \\
\hline D-14 & 97,37 & 100 & I-14 & 81,39 & 70 \\
\hline $\mathrm{D}-15$ & 88,16 & 90 & $\mathrm{I}-15$ & 97,67 & 100 \\
\hline D-16 & 86,84 & 90 & I-16 & 80,23 & 60 \\
\hline D-17 & 75,00 & 50 & $\mathrm{I}-17$ & 91,86 & 80 \\
\hline D-18 & 100 & 100 & I-18 & 81,39 & 70 \\
\hline D-19 & 97,37 & 100 & I-19 & 88,37 & 70 \\
\hline $\mathrm{D}-20$ & 86,84 & 80 & $\mathrm{I}-20$ & 88,37 & 80 \\
\hline D-21 & 94,74 & 80 & $\mathrm{I}-2 \mathrm{I}$ & 77,91 & 60 \\
\hline $\mathrm{D}-22$ & 89,47 & 90 & $\mathrm{I}-22$ & 89,54 & 80 \\
\hline $\mathrm{D}-23$ & 92,11 & 80 & $\mathrm{I}-23$ & 81,39 & 80 \\
\hline D-24 & 92,11 & 80 & $\mathrm{I}-24$ & 80,23 & 80 \\
\hline $\mathrm{D}-25$ & 90,79 & 70 & $\mathrm{I}-25$ & 88,37 & 80 \\
\hline D-26 & 97,37 & 70 & $\mathrm{I}-26$ & 83,72 & 50 \\
\hline$D-27$ & 93,42 & 70 & I- 2 ? & 77,91 & 80 \\
\hline D-28 & 82,89 & 70 & $\mathrm{I}-28$ & 88,37 & 80 \\
\hline D-29 & 75,00 & 70 & $\mathrm{I}-29$ & 89.54 & 80 \\
\hline $\mathrm{D}-30$ & 97,37 & 100 & $\mathrm{I}-30$ & 91,86 & 80 \\
\hline D-31 & 86,84 & 60 & $\mathrm{I}-31$ & 84,88 & 50 \\
\hline $\mathrm{D}-32$ & 90,79 & 80 & $\mathrm{I}-32$ & 89,54 & 70 \\
\hline $\mathrm{D}-33$ & 89,47 & 60 & $\mathrm{I}-33$ & 94,18 & 70 \\
\hline$D-34$ & 89.47 & 70 & $\mathrm{I}-34$ & 80,23 & 50 \\
\hline $\mathrm{D}-35$ & 90,79 & 70 & $\mathrm{I}-35$ & 89,54 & 70 \\
\hline$D-36$ & 86,84 & 60 & $\mathrm{I}-36$ & 88,37 & 70 \\
\hline$D-37$ & 86,84 & 60 & I-3? & 100 & 100 \\
\hline$D-38$ & 89,47 & 70 & I-38 & 86,05 & 60 \\
\hline $\mathrm{D}-39$ & 100 & 100 & & & \\
\hline$D-40$ & 97,37 & 100 & & & \\
\hline Rata-rata & 90,85 & 79,25 & Rata-rata & 88,21 & 77,89 \\
\hline
\end{tabular}

Tabel 10 menunjukkan persentase pemahaman siswa setelah pembelajaran pada kelas deduktif dan kelas induktif terhadap materi tata nama senyawa biner dan poliatomik. Rata-rata pemahaman siswa kelas deduktif diperoleh sebesar 79,25\% dengan kategori baik dan pada kelas induktif rata-rata pemahaman siswa sebesar 77,89\% dengan kategori baik. 
Kemampuan belajar dan pemahaman siswa kelas deduktif disajikan pada Gambar 3. Grafik kemampuan belajar dan pemahaman siswa diurutkan berdasarkan nilai kemampuan belajar siswa dari yang terkecil ke yang lebih besar.

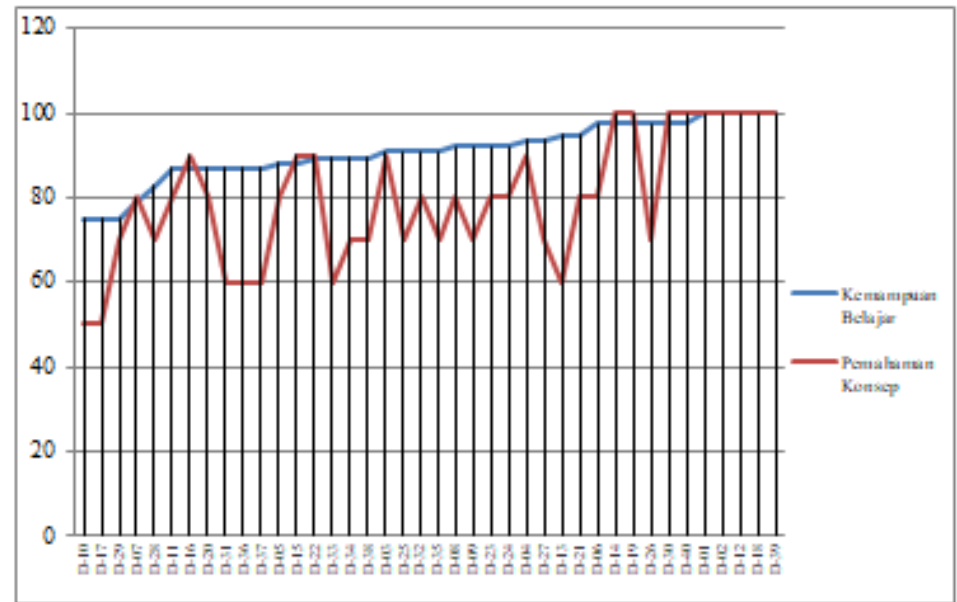

Gambar 3. Grafik Kemampuan Belajar dan Pemahaman Konsep Siswa pada Kelas Deduktif

Gambar 3 menunjukkan pemahaman setiap siswa kelas deduktif setelah pembelajaran menggunakan LKS-deduktif, terlihat bahwa semakin baik kemampuan belajar siswa maka pemahaman siswa juga cenderung meningkat.

Kemampuan belajar dan pemahaman siswa kelas induktif disajikan pada Gambar 4. Grafik kemampuan belajar dan pemahaman siswa diurutkan berdasarkan nilai kemampuan belajar siswa dari yang terkecil ke yang lebih besar.

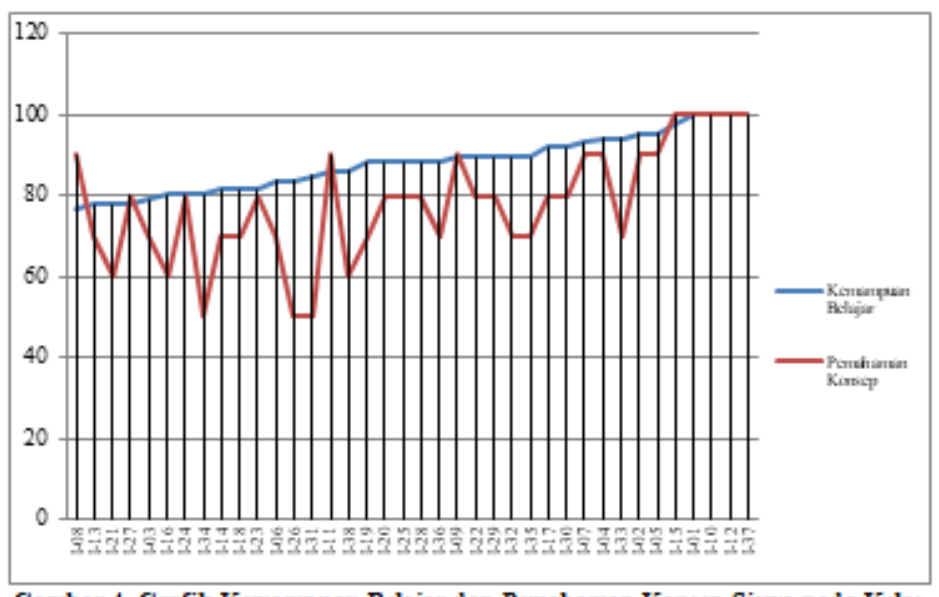

Gambar 4. Grafik Kemampuan Belajar dan Pemahaman Konsep Siswa pada Kelas Induktif 
Gambar 4 menunjukkan pemahaman setiap siswa kelas induktif setelah pembelajaran menggunakan LKS-induktif, terlihat bahwa semakin baik kemampuan belajar siswa maka pemahaman siswa juga cenderung meningkat.

Perbandingan pemahaman konsep dianalisis lebih lanjut pada setip indikator. Perbandingan secara keseluruhan pada setiap indikator ini dapat diketahui melalui perhitungan dari data tes siswa kelas deduktif dan kelas induktif. Tabel 11 yang menyajikan perbandingan pemahaman siswa pada setiap indikator konsep tata nama senyawa biner dan poliatomik.

Tabel 11. Pemahaman Konsep Siswa pada Setiap Indikator

\begin{tabular}{|c|c|c|c|}
\hline Indikator & Indikator & $\begin{array}{c}\text { Kelas } \\
\text { Deduktif }\end{array}$ & $\begin{array}{c}\text { Kelas } \\
\text { Induktif }\end{array}$ \\
\hline $\begin{array}{l}\text { Menuliskan nama senyawa biner antar } \\
\text { dua unsur nonlogam tanpa indeks }\end{array}$ & 1 & 95 & 89,47 \\
\hline $\begin{array}{l}\text { Menuliskan nama senyawa antar dua } \\
\text { unsur nonlogam jika salah satu un- } \\
\text { surnya memiliki indeks }\end{array}$ & 2 & 92,5 & 86,84 \\
\hline $\begin{array}{l}\text { Menuliskan nama senyawa antar dua } \\
\text { unsur nonlogam jika kedua unsur } \\
\text { memiliki indeks }\end{array}$ & 3 & 75 & 71,05 \\
\hline $\begin{array}{l}\text { Menuliskan nama senyawa antar unsur } \\
\text { logam dan nonlogam jika unsur logam } \\
\text { memiliki satu bilangan oksidasi }\end{array}$ & 4 & 65 & 76,32 \\
\hline $\begin{array}{l}\text { Menuliskan nama senyawa antar unsur } \\
\text { logam dan nonlogam jika unsur logam } \\
\text { memiliki bilangan oksidasi lebih dari } \\
\text { satu }\end{array}$ & 5 & 55 & 50 \\
\hline $\begin{array}{l}\text { Menuliskan nama senyawa poliatomik } \\
\text { jika kation memiliki satu bilangan } \\
\text { oksidasi }\end{array}$ & 6 & 80 & 86,84 \\
\hline Menuliskan nama senyawa basa & 7 & 95 & 94,74 \\
\hline $\begin{array}{l}\text { Menuliskan nama senyawa poliatomik } \\
\text { jika kation memiliki bilangan oksidasi } \\
\text { lebih dari satu }\end{array}$ & 8 & 60 & 68,42 \\
\hline $\begin{array}{l}\text { Menuliskan nama senyawa asam jika } \\
\text { unsur hidrogen tidak memiliki indeks }\end{array}$ & 9 & 87,5 & 73,68 \\
\hline $\begin{array}{l}\text { Menuliskan nama senyawa asam jika } \\
\text { unsur hidrogen memiliki indeks }\end{array}$ & 10 & 90 & 81,58 \\
\hline Rata-rata Indikator & & 79,25 & $\mathbf{7 7 , 8 9}$ \\
\hline
\end{tabular}


Data pada Tabel 11 menunjukkan bahwa rata-rata pemahaman konsep kelas deduktif sedikit lebih tinggi dibandingkan kelas induktif. Pada indikator 1, indikator 2 , indikator 3 , indikator 5 , indikator 7 , indikator 9, dan indikator 10 ratarata pemahaman konsep siswa yang menggunakan LKS-deduktif lebih baik dibandingkan siswa yang menggunakan LKS-induktif sedangkan pada indikator 4, indikator 6 , dan indikator 8 pemahaman siswa yang menggunakan LKSinduktif lebih baik dibandingkan pembelajaran menggunakan LKS-deduktif.

\section{Simpulan}

Pemahaman konsep tata nama senyawa biner dan poliatomik pasca pembelajaran menggunakan LKS-deduktif dan LKS-induktif pada siswa kelas X SMA Negeri 2 Palangka Raya tahun ajaran 2018/2019 tergolong baik dengan ratarata kelas deduktif sebesar 79,25\% dan rata-rata kelas induktif sebesar 77,89\%. Rata-rata pemahaman konsep siswa yang menggunakan LKS-deduktif sedikit lebih tinggi dibandingkan siswa yang menggunakan LKS-induktif. Hasil tersebut dikarenakan siswa lebih sering menggunakan strategi belajar deduktif daripada strategi belajar induktif.

\section{Daftar Rerensi}

Suharsimi, A. 2010. Prosedur Penelitian (Edisi Revisi 2010). Jakarta: Rineka Cipta.

Costa, A. L. 1988. (Ed): Developing Minds: A Resource Book for Teaching Thinking. Virginia: ASCD.

Hengki. 2015. Pemahaman Konsep Tata Nama Senyawa Biner dan Poliatomik dalam Pembelajaran Menggunakan Metode Diskusi dengan Berbantuan LKS-Deduktif pada Siswa Kelas X SMK Negeri 1 Palangka Raya Tahun Ajaran 2014/2015. Skripsi Sarjana. Tidak diterbitkan, Universitas Palangka Raya. 
Olvi Wulan Nari (149-160)

Majid, A. 2005. Perencanaan Pembelajaran Mengembangkan Standar Kompetensi Guru. Bandung: Remaja Rosdakarya.

Uno, H. B. 2006. Perencanaan Pembelajaran. Jakarta: PT Bumi Aksara.

Yamin, M. 2013. Desain Pembelajaran Tingkat Satuan Pendidikan. Ciputat: Referensi. 